\title{
Perceived Relationship between Ethical Standards and Financial Reporting Quality in Rivers State
}

\author{
Obiaga Johnson Chinedu, Ikiriko Hope Odhuluma
}

\begin{abstract}
This paper delved into the link between ethical financial standards and financial reporting quality. Data were collected from 45 accountants in selected companies in Port Harcourt, Rivers State. The Pairwise correlation was applied to scrutinize the data. The outcomes disclosed that integrity and objectivity were positively and substantially related to timeliness and adequacyof financial reports. Based on the results of the study, it is recommended amongst others that engagement processes of firms should be enhanced so that men and women with top level of ethical standing would be appointed. Companies in Nigeria must provide principles and conformity unit to guide and supervise ethical application in their everyday tasks; companies reportage arrangement must follow closely the financial reporting structure disseminated by the International Financial Reporting Standards for healthier and more satisfactory financial reports; accountants as upholders of reliable financial reports must adhere to the principles of professional practice issued by the Institute of Chartered Accountants of Nigeria (ICAN), ACCA, CPA, ANAN for their everyday duties; and all the relevant professional accounting bodies in Nigeria should scrutinize the actions of their associates to certify that the rules of ethics are adhered to in the formulation of quality financial reports in the country.

Index Terms - Ethical accounting standards, ethics, integrity, objectivity, independence, competence, confidentiality, financial reporting quality.
\end{abstract}

\section{INTRODUCTION}

As Nigeria moves to achieve her vision of being one of the top 20 economies in the world by the year 2030, one prevailing issue that remains on the front burner is how to build investors' confidence in the national economy through ethical accounting and auditing standards that enhance transparent financial reporting. The disastrous failures and scandals of some corporate giant and the extensive corruption in the society highlight the critical need to pay attention on the pillars of sound professional ethics within the professions of accounting \& auditing in developed and emerging countries (Omoyele, 2010; Fodio, Ibikunle\& Oba, 2013; Ogbonna \&Ebimobowei, 2012).

Recently, the disquiet regarding issues of ethics and integrity in the accounting \& auditing profession is on the rise as it pertains to questionable acts in both public and private domain. Thus, series of ethical negligence, corporate failures, auditing and accounting scandals have all left their marks on the economies of developed and emerging nations

Obiaga, Johnson Chinedu (PhD), Department of Accounting, Faculty of Business Administration, University of Nigeria, Enugu State, Nigeria. Ikiriko,Hope Odhuluma, Department of Accounting, Faculty of Management Sciences, University of Port Harcourt, Rivers State, Nigeria. respectively. Damagum \& Chima, (2014) agreed that evidence in prior research showed that poor corporate governance attributes to such failures, hence the need to keep vigil over corporate entities behaviors besides the need to control the behavior of managers and professional accountants through effective regulations. Publicized cases like that of WorldCom, Enron, Xerox to name a few and indigenous Nigerian firms like Cadbury and Afri-bank (that got a top reputable auditing firm in Nigeria indicted) all draw collective attention to the auditing profession. The collapses of these companies have been attributed to accountants and auditors not sticking to the canons of professional ethos.

With regards to Beverly et al (2007), certain factors are known for contributing to unethical behaviours and these factors includes; failure to maintain objectivity and independence, improper leadership and ill culture, self-interest, lack of competence, lack of ethical sensitivity, inappropriate professional judgment, lack of organizational and peer supports, failure to withstand advocacy threats, and a lack of professional body support.

\section{A. Statement of the Problem}

Individual occasionally have to face ethical dilemmas and the problem of weakness of will with accountants being no different. Working as an accountant, encountering situations where the temptation to choosing between right or wrong is well known. That is why a feature of accountancy's claim to professionalism is its commitments to ethical standards. This involves an assurance that the accountancy bodies and their members will not pursue their material self-interests in ways that conflict with their duties to the public interest (Appah, 2010). There is an integrated code of ethics for every profession to ensure ethical behaviour on its members as observed by Mathews and Perera (1996). The Nigerian society over time has witnessed a good amount of corporate scandals in the financial (Oceanic Bank, etc.) and non-financial (Cadbury Plc. and African Petroleum) sectors of the economy.

Ogbonna (2010) discusses that any organization lacking ethical consideration may not survive long-term to attain its desired goals and objectives and that of its stakeholders. These failures of corporate entities have been attributed to accountants not adhering to the codes of conduct evidenced not only in the contents of financial statements but also in its reliability by end users. Hence, adequate care has to be taken on how these financial statements are presented. Aguolu (2006) says that these failures have brought to greater scrutiny the work of the accountant from both within the profession and from outside. Several ethical issues have been discussed in recent times ranging from conflict of interest, 
insider's dealings, objectivity, acceptance of gifts etc. scholars are of the opinion that all these ethical issues affect the quality of financial statements. The code of corporate governance (2011) provides for the composition of an ethics committee in an organization where the committee is responsible for deliberating on ethical issues as well as upholding ethical standards in the organization. This has not really yielded the right result as intended as some of the scandals over the past decade have been traced to ethical issues where most times management and auditors compromised integrity for personal and selfish gain to the detriment of the organization. Enron manipulated its statement through off balance sheet financing because they lacked independence from senior executives, Cadbury overstated its audited financial statements, African Petroleum (AP) concealed its indebtedness to the tune of 22 billion, the financial sector crisis also witnessed few years ago also revealed that the banks connived with the auditors to issue a true and fair view. A critical look at all these cases show that they all were as a result of the violation of ethical practices, hence there's need to critically appraise ethical issues in an organization and how they affect financial reporting quality.

\section{B. Objectives of the Study}

The aim of the study is to examine the relationship between ethical accounting standard and financial reporting quality in Nigeria. Specifically, the study aimed at:

i. Analyzing the perceived relationship between ethical accounting standard and timeliness;

ii. Evaluating the perceived relationship between ethical accounting standard and adequacy;

\section{Operational Framework}

Thisstudy is guided by the operational framework below

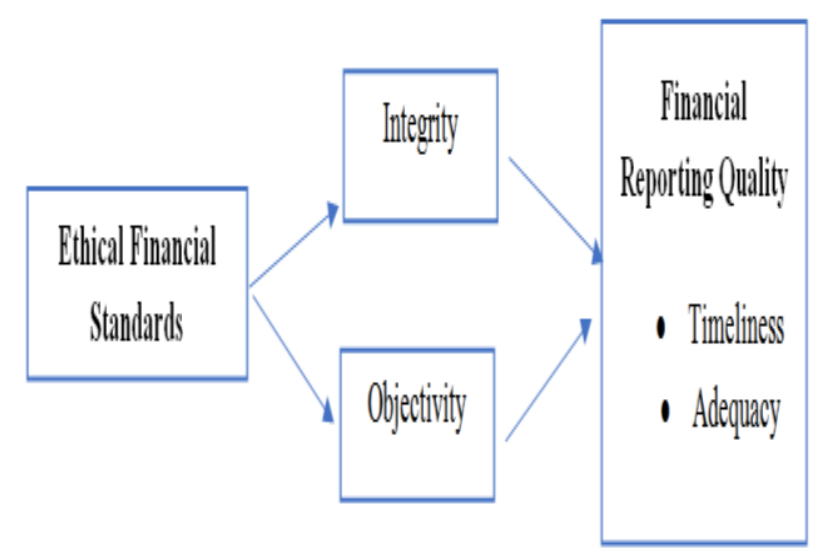

Figure 1: Operational Framework on Ethical Accounting Standards and Financial Reporting Quality

Source: From Review of Related Literature

\subsection{Research Hypotheses}

A hypothesis is a theoretical conceptualization that has not been empirical tested. It is a set of assumptions that serve as the basis of an investigation. For the purpose of this research, the following hypotheses were formulated and tested.

1: There is no significant relationship between ethical accounting standard and timeliness.
2: There is no significant relationship between ethical accounting standard and adequacy.

\section{Scope and Limitation of the Study}

The study investigated the relationshipbetween ethical accounting standard and financial reporting quality in Nigeria. It covers the variables stated in the hypotheses. The study used primary data sourced from accountants in Rivers State. The study is limited by the area of study. The study was also constrained by the availability of financial resources among others.

\section{LITERATURE REVIEW}

\section{A. Theoretical Framework}

This study uses the stewardship theory as a theoretical background to develop an empirical framework for examining the relationship between ethical accounting standards and financial reporting quality. The contractual relationship existing amongst the stakeholder (owners of the company), the upper echelon, board of directors and external auditors is one which is purely a stewardship relationship (Adelegan, 2009). This study is naturally framed by the stewardship theory since financial reporting concerns came about because of dissociation of company by their owners and hence those entrusted with managing and overseeing the affairs of the company in the interest of the owners are expected to render stewardship of their duties i.e. validating of financial report by independence professional party (External Auditors).

Therefore, those individuals aspiring to be part of the stewardship of management do so to be at the forefront of economic decisions; which may include the decision to either sell or hold their investments in an organization or to reappoint or replace the management. The stewardship objective has been considered as being about information that provides a basis towards a constructive dialogue amongst the management and investors. This is deemed to be essential response to the development of a contemporary company and a fundamental corner stone of corporate financial reporting. It is equally advocated that, whilst this dialogue takes place over various channels and forms, it is crucial to note that the roles played by reporting accountants and external auditors are part of what shapes this dialogue (Accounting Standards Board, 2007).

\section{B. Ethical Financial Standard}

Ethics pertains to those moral principles that guide the behaviour of an individual. Ethics is concerned with the systematic examination of matters of good and bad, right and wrong, virtues and vice (Brinkmann, 2002; Ogbonna \&Appah, 2012). Ethics looks at human behavior, moral principles and the effort to separate good from bad. Ethics represent a set of moral principles, rules ofconduct or values. Ethics apply when an individualhas to stand by a decision regarding various alternatives concerning moral principles.

Hayes, Schilder, Dassen\&Wallage (1999), Aguolu (2006), describes ethics to be guidelines, principles, characteristic and morals regarding personal demeanor and unwritten convention guiding the behaviour and conduct of an 
individual, group of people or society as they interact with each other or relates to other people in regards to business or other social associations. Ethical behaviour is vital if society must function properly. Ethic is requisite in a society and thus amply important so much so that commonly perceived ethical values of a society for instance loyalty, integrity and pursuit of excellence can be integrated into law.

\section{Integrity}

In all professional and business relationships, a professional accountant needs to be honest and straight forward. Jenfa (1998) opined that it is the duty of a professional accountant to avoid conflicting interest either actual or apparent. Actions that will result in prejudice of duties in an unethical manner need to be refrain from by professionals. Osisioma (2000), attest that professionalism is ultimately tested by integrity; being in a complete and unified state.When accountants have integrity their words and deeds will match up. He further notes that integrity and the spirit of present time are antithetical. The primary philosophy of life shepherding our culture revolves around a materialistic consumer mentality. Maxwell (1993) in Nwagboso (2008) opines that integrity is not a given factor in everyone's life. It is by virtue of inner trust, self-discipline and a decision in being inexorably honest in all situations in our existence. Unfortunately, strength of character is a rare trait in today's world. Consequently, contemporary models of integrity are scares. Our culture has nurtured few enduring idols, few models of virtue. We have turned into a nation of imitators with few leaders worth imitating. A professional accountant should not be linked with reports, returns, communications or other information believed to contain materially fabricated or misleading statements.

\section{Objectivity}

All professional accountants are imposed by the principle of objectivity to be impartial, honest and free form conflict of interest and should refrain from prejudice or being swayed by others to override their professional judgement of the mind often desorbed as independence. Jenfa (1998) contends that it is the responsibility of a professional accountant to converse information impartially and objectively and disclose entirely all relevant information probable of influencing an intended user's understanding of the reports, remarks and recommendations presented. The IFAC (2006) code of ethics for professional accountants identifies that the objectives of accountancy professional are to work to the highest standards of professionalism, to attain the highest levels of performance and generally to meet the public interest requirement (Adebayo, 2005).

\section{Financial Reporting Quality}

Financial reporting is an essential element required by the corporate governance system to function successfully. It is expectant of accountants and auditors who are key providers of information to participants of the capital marker to apply high standards of due care and demonstrate professional competence in the accounts audited by them. The company directors expect that the financial statements prepared by the management are in compliance with necessary statutory and ethical obligations, and trust on the auditors' competency and creditability (Dignam \& Lowry, 2006).

The main objective of corporate financial report offers information regarding the financial standings of a firm (strength, performance and changes in financial position) which are beneficial to users in decisive economic decisions (Benston, 2007). This report needs to be understandable, reliable, significant and comparable. When financial statements are doctored through creative accounting or earning management, the true stand of the financial performance of the reporting entity is lost, which correspondingly misleads various stakeholders in taking erroneous decisions and even undergo economic damages.Under these circumstances, the auditors and accountants are indicted in an accounting scandal or corporate fraud or when financial misappropriation or corporate failure occurs as a result of professional negligence of due care, unethical practice and compromise or collusion just like cases involving Ernon, WorldCom, Cadbury, Lever Brothers Nigeria, and a host of others (Salisu, 2007). Proves of accountant and auditors getting involved in unethical practices and conflicts of interest have been documented by numerous scholars of accounting in developed and emerging countries (García-Benau\& Humphrey, 1992; McHugh and Stamp, 1992; Sikka \& Willmott, 1995; Bakre, 2007; Sikka,2009; Otusanya\&Lauwo, 2010).

\section{Timeliness}

Conflict between relevance and reliability can arise over the timeliness of information. If there is undue delay in the reporting of information making it out of date, then this will affect its relevance. On the other hand, reporting on transactions and other events before all the uncertainties involved are resolved may affect the information's reliability. This information cannot be omitted as omitting information from the financial statements because of reliability concerns may affect the completeness, and therefore reliability of the information provided. If reporting is delayed until the underlying information is reliable, it may be of little use to users who have economic decisions to make in the interim. In reaching a balance between timeliness and relevance and reliability, the entity should take all steps possible to produce reliable information in a timely manner. $\mathrm{T}$ e overriding consideration affecting the timing of reporting should be 'how best to satisfy the information needs of users for economic decision-making (Sikka, 2009).

\section{Adequacy}

According to the financial reporting qualitative frameworkinformation is adequate if it has the ability to sway the economic decisions of users by assisting them to evaluate past, present or future events or confirming, or correcting, their past evaluations. Therefore, according to the frameworkadequate information should have predictive value or confirmatory value. Information is said to have predictive value if it can assist a user in evaluating or assessing past, present and future events. Information leaking explicit forecast can be said to have predictive value. However, the manner in which past information are presented in a financial statement improves the ability to predictions. For this reason, 
comparatives are provided and exceptional, one-of and abnormal items are identified separately in the financial statements from normal activities. In addition, transactions involving newly acquired businesses, or businesses that are being disposed of, are re-analyzed and separately disclosed from transactions from continuing operations. Therefore, variations in the performance and financial position of the entity resulting from normal activities likely to be in continuity in the future can be determined by a diligent user. Confirmatory value is assigned to information if it helps confirm or correct past evaluations and assessments done by a user. Though it is commonly considered that adequate information is more relevant when it is provided in a timely manner as it is more likely to influence decision-making (Otusanya\&Lauwo, 2010).

\section{Empirical Review}

Mahdi and Mohsen (2011) by looking at the impact of professional accounting ethics on financial reporting quality in Iran through the use of a 24-item questionnaire with a sample of 205 companies in Iran were able to conclude that the quality of financial reporting is significantly impacted by professional accounting ethics.

Masoud and Mahbude (2013) when looking at the impact of professional accounting ethics on financial reporting quality established that promoting financial reporting quality can be achieved by developing professional ethics in the field of accounting. Tae and Jinhan (2011) wrote about effect of business ethics on financial reporting quality using Korea firms. They discovered that companies that had a higher level of ethical commitment were less engaged in earning management, were more conservative in reporting earnings, and accurately predicted future cash flow better as compared to those with lower level of ethical commitment. In addition, it was also discovered that the effect of corporate commitment to business on future financial reporting quality is one that is continuous.

Ogbonna and Appah (2011) when studying the effect of ethics on financial reporting quality in Nigeria by utilizing a sample of 123 accountants opined that ethical compliance by the accountant significantly affects the quality financial reports in a positive manner. Flugrath, Bennie \& Chen (2007) after looking ethics and financial reporting quality using primary data on a sample of 112 professional accountants revealed that the quality of the judgment made by professional accountants is positively impacted by the presence of ethics.

Berrone, Suroca andTribo (2009) by using OLS regression on data from 515 companies revealed that a strong corporate ethical identity was positively related to high levels of stakeholder satisfaction. In consideration, the financial performance of the firm was positively influenced by stakeholder satisfaction.

\section{Methodology}

The research design adopted for this study is the survey research design as it enables the researcher elicits information from the respondents on the subject matter under investigation. Primary data was used for this study and it was gotten through the use of a 5-point Likert's Scale questionnaire. The population comprised of all accounting practitioners in Nigeria. The sample was restricted to accounting practitioners in Port Harcourt. A total of fifty copies of the questionnaire were used for data collection. The data generated were analyzed using the Pairwise Correlation Coefficient.

\section{ANALYSIS AND DISCUSSION OF RESUltS}

This section of the study strictly lay emphasis on presentation, analysis and interpretation of the data obtained on the field work through the administered questionnaire which were distributed to the sampled organization in line with the objectives of the study. In view of the above, in order to validate or reject the null hypotheses earlier formulated in section one of this study, the hypotheses were tested by the researcher using the Pairwise Correlation Coefficient and the results were interpreted to fulfill the purpose of which this study was carried out. The data presentation started by showing the analysis of figures and percentages of copies of questionnaire administered, and the numbers returned by the respondents of the selected companies for the study. From the table, a total of fifty (50) copies of questionnaire were handed out to respondents of the selected companies for the study, of which $45(90 \%)$ copies questionnaire were returned by the respondents as shown by table 4.1 .

\section{A. $\quad$ Showing Questionnaire Distributed and Returned}

\begin{tabular}{|c|c|c|}
\hline $\begin{array}{c}\text { Questionnaire } \\
\text { Distributed }\end{array}$ & $\begin{array}{c}\text { Questionnaire } \\
\text { Returned }\end{array}$ & $\begin{array}{c}\text { Percentage } \\
(\boldsymbol{\%})\end{array}$ \\
\hline 50 & 45 & 90 \\
\hline
\end{tabular}

B. Data Analysis

Table 2: Correlation Results

\begin{tabular}{|l|l|l|}
\hline Variables & Timeliness & Adequacy \\
\hline Integrity & 0.650 & 0.452 \\
& $(0.001)$ & $(0.002)$ \\
\hline Objectivity & 0.629 & 0.502 \\
& $(0.000)$ & $(0.000)$ \\
\hline
\end{tabular}

Source: Result from Appendix B

The probability values are written in parentheses.

The above table 4.2 shows the Pairwise Correlation Coefficient results for the dimensions of ethical accounting standard and measures of financial reporting quality. The result indicates that improving integrity will increase timeliness of financial report, promote adequacy of financial disclosure by $65 \%, 45.2 \%$ respectively. This means that integrity helps accountants to put in their best on a given job. The implication of this is improvement in financial reporting quality.

It could be seen from the result that objectivity has positive influence on timeliness, adequacy.

The result showed that approximately $62.9 \%, 50.2 \%$ improvement in timeliness of financial report, adequacy of financial disclosure is by reason of the accountant's objectivity. This result affirms the findings of Masoud and Mahbude (2013) who found that upholding financial reporting quality can only be done by developing professional 
ethics in accounting.

\section{Hypotheses Testing}

\section{Hypothesis One}

1: There is no significant relationship between ethical accounting standard representing and timeliness.

Since probability values $(0.001$ and 0.000$)$ are less than the critical value (0.05) using a two-tailed test, the study concludes by accepting the alternate hypothesis which imply that the relationship between ethical accounting standard and timeliness of financial reporting is significant.

\section{Hypothesis Two}

${ }_{2}$ : There is no significant relationship between ethical accounting standard and adequacy.

Since probability values $(0.002$ and 0.000$)$ are less than the critical value (0.05), the study concludes by accepting the alternate hypothesis which imply that the relationship between ethical accounting standard and adequacy of information disclosure is significant.

\section{CONCLUSION}

In this study, the perceived relationship between ethical accounting standard and quality of financial reports of Nigerian firms was evaluated. The hypotheses were tested using the Pairwise Correlation Coefficient on the data from the administered questionnaire. Data analysis revealed that the relationship between accounting ethics and financial reporting quality is significant. This agrees with the findings of Ogbonna and Appah (2011) that the quality of financial reports of organizations principally depends on the ethics in the accounting profession. Thus in regards to the findings, it is the conclusion of the study that high ethical standard is intrinsic to actualizing quality financial reporting.

\section{RECOMMENDATIONS}

The subsequent suggestions are postulated to enhance the framework of financial reporting.

1. Companiesshould take a look at upgradingtheir employment process so as to appointpersonswith high level of ethical standards.

2. There is a need for principlesand conformityunitin Nigerian firms to guide andsuperviseethical application in their everydayoperations.

3. Companies reportage arrangementmustfollow closely the financial reporting structure disseminated by the International Financial Reporting Standards for healthier and more satisfactory financial reports.

4. Accountants as upholders of reliable financial reports must adhere to the principles of professional practice issued by the Institute of Chartered Accountants of Nigeria (ICAN), ACCA, CPA, ANAN for their everyday duties.

5. All the relevant professional accounting bodies in Nigeria should scrutinize the actions of their associates to certify that the rules of ethics are adhered to in the formulation of quality financial reports in the country.

\section{REFERENCES}

[1] Adebayo, A. (2005). Financial reporting: An aid to efficient economic management in the public sector. The Nigerian Accountant, 38(1), 33-38.

[2] Aguolu, E. O. (2006). Ethics and integrity in the accounting profession. The Nigerian Accountant, 39(4), 31 -34.

[3] Aminu, A. A. \& Oladipo, O. O. (2016). Application of financial ethics in annual financial reporting of banks. Journal of Economic and Social Development, 3(1), $66-75$.

[4] Beverly, J., Barry, J. C., Phil, L \& Steven, D. (2007). Professional accounting bodies' perception of ethical issues, causes of ethical failure and ethics education. Managerial Auditing Journal, 22(9), 23 36.

[5] Companies and Allied Matters Act of Nigeria (CAMA 1990)

[6] Damagum, Y. M. \&Chima, E. I. (2014). An empirical analysis of corporate governance codes. Accountability vs enterprise: Evidence from Nigeria. International Journal of Accounting and Finance, 3(1), $34-45$.

[7] Dechow, P. W. \&Schrand, C. (2010). Understanding earnings quality: $A$ review of the proxies, their determinants and their consequences. Review of Accounting Studies, 8, 355-384.

[8] Eginiwin, J. E. \& Dike, J. W (2014). Accounting ethics and the quality of financial reporting: A survey of some selected oil exploration and producing companies in Nigeria. Journal of Business and Management. 16(7), 26-36.

[9] Ewert, R. \&Wagenhofer, A. (2010), Earnings quality metrics and what they measure, Working paper, University of Graz.

[10] Fodio, M. I, Ibikunle, J. \& Oba, V. C. (2013). Corporate governance mechanisms and reported earnings quality in listed Nigerian insurance firms. InternationalJournal of Finance and Accounting, 2(5), 279-286.

[11] Hayes, R., Schilder, A., Dassen, R. \&Wallage, P. (1999). Principles of auditing: An international perspective. McGraw-Hill Publishing Company, Berkshire.

[12] Institute of Chartered Accountant of Nigeria (ICAN) 1998

[13] International Federation of Accountants Committee (IFAC) (2006). Code of ethics.

[14] International Federation of Accountants Education Committee (2003) International education standards for professional accountants, available at http://www.ifac.org.

[15] Ofurum, C. O. \& Ogbonna, G. N. (2008). Accounting information system: A functional approach. Bon Publication, Owerri.

[16] Jenfa, B. I. (2000). Elements of professionalism and practice of accountancy Jos: Ehindero Nig. Ltd.

[17] Mathews, M. R. \&Perera, M. H. B. (1996). Accounting theory and development. International Thomson Publishing, South Melbourne.

[18] Nwachukwu, C. C. (2007). Management theory and practice. Onitsha: Africana First Publishers Ltd.

[19] Nwagboso, J. (2008). Professional ethics, skills \& standards. Jos: Inspiration Media Konsult, Maiden Edition.

[20] Ogbonna, G. N. \&Ebimobowei, A. (2012). Effect of ethical accounting standards on the quality of financial reports of banks in Nigeria. Current Research Journal of Social Sciences 4(1), 69-70.

[21] Omoyele O.V. (2010). Corporate governance at post coordination in the Nigeria banking industry.

[22] Osisioma, B. C. (2000). Ethics and professionalism: The challenge for the Certified National Accountant (ANAN) mandatory continuous professional development (MCPD) lectures, May 23, Enugu, Nigeria.

\section{APPENDIX A}

\section{QUESTIONNAIRE}

\section{SECTION A}

Please fill in the space and tick $[\sqrt{ }]$ in the appropriate place

1. What is name of your organization?

2. What is your sex? ..............................

3. How long have you been practicing accounting profession?

4. What is your qualification?

5. What are the dimensions of ethical financial standard?

$\begin{array}{ll}\text { a. Integrity } & {[\mathrm{]}} \\ \text { b. Objectivity } & \text { [ ] }\end{array}$

6. What are the measures of financial reporting quality?
a. Timeliness
b. Adequacy
[ ]

SECTION B

7. To what extent do you agree that integrity influences timeliness? 
Strongly agree [ ] Agree [ ] undecided [ ] Disagree [ ] Strongly Disagree [ ]

8. To what extent do you agree that integrity influences adequacy?

Strongly agree [ ] Agree [ ] undecided [ ] Disagree [ ] Strongly

Disagree [ ]

9. To what extent do you agree that objectivity influences timeliness?

Strongly agree [ ] Agree [ ] undecided [ ] Disagree [ ] Strongly Disagree [ ]

10. To what extent do you agree that objectivity influences adequacy?

Strongly agree [ ] Agree [ ] undecided [ ] Disagree [ ] Strongly

Disagree [ ]

APPENDIX B

Table A: Responses from Respondents on the Questionnaire Items

\begin{tabular}{|c|c|c|c|c|c|c|}
\hline $\mathbf{S} / \mathbf{N}$ & Research Questions & SA & $\mathbf{A}$ & $\mathbf{U}$ & D & SD \\
\hline 7 & To what extent do you agree that integrity influences timeliness? & 23 & 10 & 3 & 4 & 5 \\
\hline 8 & To what extent do you agree that integrity influences adequacy? & 20 & 15 & 2 & 3 & 5 \\
\hline 9 & To what extent do you agree that objectivity influences timeliness? & 17 & 13 & 3 & 3 & 9 \\
\hline 10 & To what extent do you agree that objectivity influences adequacy & 18 & 17 & 2 & 3 & 5 \\
\hline
\end{tabular}

Source: Field Work

$\mathrm{SA}=$ Strongly Agree

$\mathrm{A}=$ Agree

$\mathrm{U}=$ Undecided

$\mathrm{D}=$ Disagree

$\mathrm{SD}=$ Strongly Disagree 